\title{
Gravity Data from the Teboursouk Area ("Diapirs Zone", Northern Tunisia): Characterization of Deep Structures and Updated Tectonic Pattern
}

\author{
Fatma HACHANI ${ }^{1}$, Hadhemi BALTI ${ }^{2}$, Ali $\mathrm{KADRI}^{2}$, \\ and Mohamed GASMI ${ }^{2}$
}

\footnotetext{
${ }^{1}$ Water Researches and Technologies Centre (CERTE), Technopark of Borj Cedria, Soliman, Tunisia; e-mail: hachani_fatma@yahoo.fr

${ }^{2}$ Department of Earth Sciences, Faculty of Sciences of Bizerte, University of Carthage, Tunisia
}

\begin{abstract}
Located between eastern segments of the Atlas and Tell-Rif orogenic belts, the "Dome zone" of northern Tunisia is characterized by the juxtaposition of various structures that mainly controlled the long geodynamic history of this part of the south-Tethyan Margin. To better understand the organization and deep extension of these structures, gravity data from the Teboursouk key area are proposed. These data include the plotting of Bouguer anomaly map and related parameters such as vertical and horizontal gradients, upward continuation and Euler solution. Compared to geological and structural maps available, they allow the identification of new deep structures and greater precision regarding the characteristics and organization of known ones; consequently, an updated structural pattern is proposed.
\end{abstract}

Key words: Northern Tunisia, Teboursouk, gravity data, deep structure, diapir, faults.

Ownership: Institute of Geophysics, Polish Academy of Sciences;

(c) 2016 Hachani et al. This is an open access article distributed under the Creative Commons Attribution-NonCommercial-NoDerivs license,

http://creativecommons.org/licenses/by-nc-nd/3.0/. 


\section{INTRODUCTION}

Northern Tunisia is an extension of the Tell-Rif eastern segments and the north-Atlasic domain (Fig. 1A). It is considered as one of the important sectors where the complex geological history of the Maghrebian south-Tethyan Margin can be reconstructed. In fact, at least since the Triassic period, this area has undergone many tectonic episodes that alternated through time. Edi-

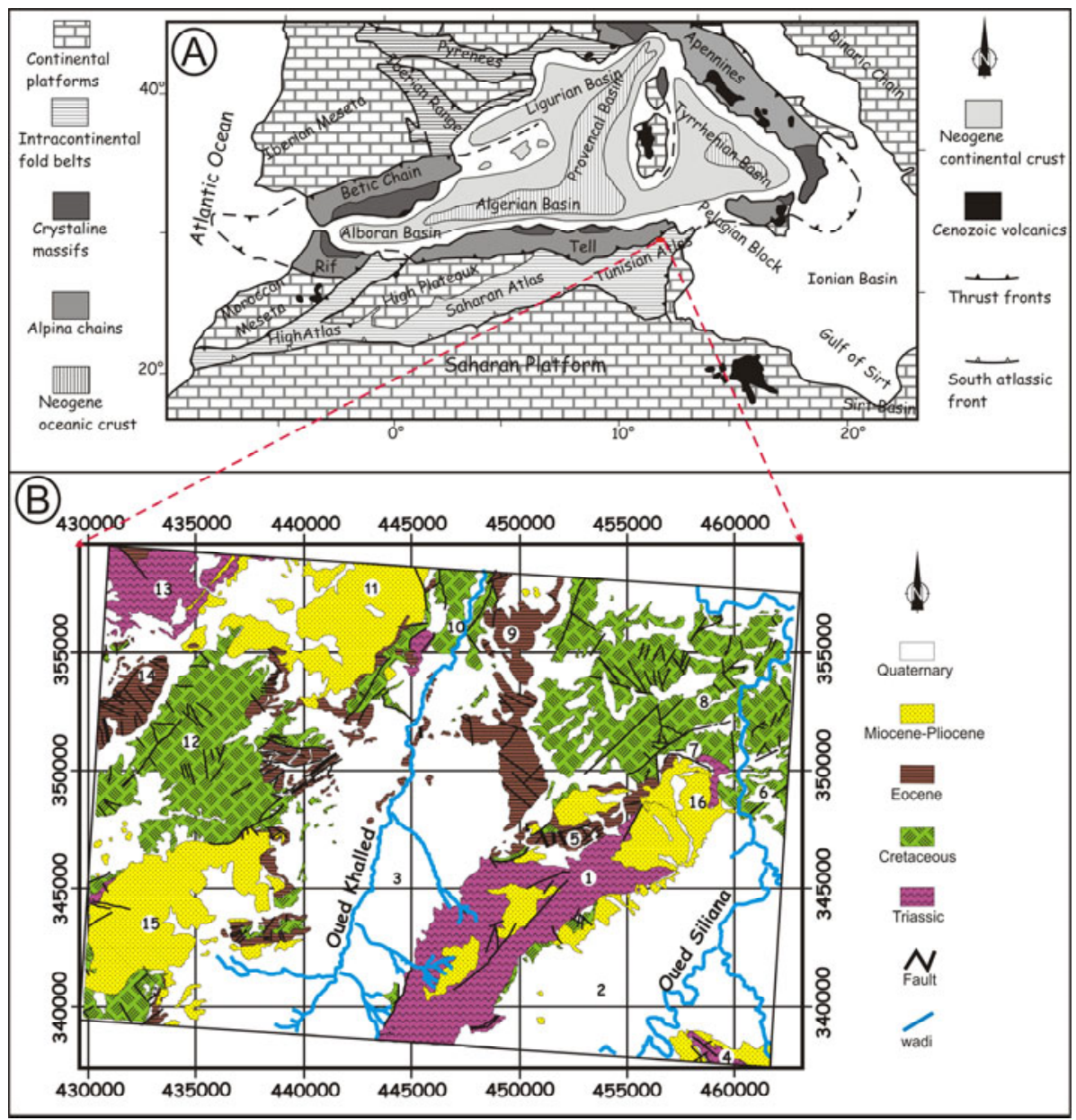

Fig. 1: (A) Tectonic pattern of the western Mediterranean domain (modified from Doglioni et al. 1999), (B) geological map of the study area (extracted from geological map of Teboursouk, 1:50000). 1 -Jebel Ech Cheid, 2 - plain of El Aroussa, 3 - plain of Khalled, 4 - jebel Strassif, 5 -jebel Chetlou, 6 - Koudiat el Mahjbia, 7 - Knana, 8 - Tabet Ech Cherif, 9 - Ain Tounga Khalled, 10 - Ain Jemala, 11 - Oued Hermoucha, 12 - Oued Arkou, 13 -Thibar, 14 - Jebel Goraa, 15 - Ain Hamra-Dougga, 16 - Draa el Kantra. 
fied structures were repeatedly affected by successive phases leading to the present-day structure. A set of various structures at different scales can record signatures of the main steps of this geodynamic evolution. The Teboursouk area belongs to the "Diapirs zone" of northern Tunisia which is adjacent to the northernmost Atlasic domain. Since the 1920s, particular attention has been paid to this key sector by many geologists interested in thematic investigations aiming at the reconstruction of geodynamic evolution of the Tunisian Tethys Margin and its controlling factors (Biely et al. 1974, Ben Ayed 1994, Chihi 1995, Gueguen et al. 1998, Guiraud et al. 2005, Rigane and Gourmelen 2011). The stratigraphical succession disturbance, the tectonic style, and the onset mode of the characteristic Triassic material are still a matter of debate; the drowning or burial of many structures makes it difficult to follow the continuation of structural units. In the gravimetric study, the subject of this paper, we propose to follow the distribution of density contrasts due to depressions and faults aiming to increase our understanding of the deep geological structure using unpublished gravity data (Hachani 2006). Interpretation of the Bouguer anomaly map and related derivative compilations serve as a base for deep structures' characterization; an updated tectonic pattern is proposed for the area replaced in its broader geodynamic context.

\section{GEOLOGICAL AND PALAEOGEOGRAPHICAL CONTEXT}

In northeastern Tunisia, the Teboursouk area $\left(672 \mathrm{~km}^{2}\right)$ is located one hundred kilometres to the NW of Tunis (Fig. 1B), between Lambert coordinate lines: $X=430 \mathrm{~km}$ and $X=462 \mathrm{~km} ; Y=338 \mathrm{~km}$ and $Y=359 \mathrm{~km}$ ).

As a part of the "Diapirs zone", it records many stratigraphic and structural signatures of the geodynamic evolution of the eastern Maghreb Tethyan margin. By Middle to Upper Triassic, the northern Tunisia passive margin registered the first echoes of a distensive phase, better expressed after the fragmentation of the Liassic initial carbonate platform (Solignac 1927, Bolze 1950, Rouvier 1985, Ben Ayed 1986). Consequent subsidence reached its maximum during Middle Jurassic and continued until Lower Cretaceous, all in a Tethyan rifting context related to Africa-Eurasia relative movement. As a result, a mosaic of high blocks and adjacent depressions, separated by reactivated Hercynian faults, characterizes the main palaeogeographical features of the area. A northward more subsiding area, the "Tunisian Trough", developed in a tilted-block-structural pattern allowing progressive ascentional movement of Triassic material. This material has pierced its sedimentary cover since the Albian times (Chitta 1979, Perthuisot 1979, Rouvier 1985, Dali 1997) and underlined NE-SW-trending major faults. 
Table 1

Lithological synthesis of Teboursouk

\begin{tabular}{|c|c|c|c|c|}
\hline Age & Stages & Formations & $\begin{array}{l}\text { Lithostratigraphic } \\
\text { descriptions }\end{array}$ & $\begin{array}{l}\text { Densities } \\
{\left[\mathrm{g} / \mathrm{cm}^{3}\right]}\end{array}$ \\
\hline $\begin{array}{l}\text { Quaternary } \\
(40 \text { to } 50 \mathrm{~m})\end{array}$ & & & $\begin{array}{l}\text { limestone, clay, } \\
\text { silt et conglomerates }\end{array}$ & \multirow{6}{*}{$1.7<d<2.38$} \\
\hline \multirow{4}{*}{ Neogene } & $\begin{array}{l}\text { Pliocene } \\
(20 \mathrm{~m})\end{array}$ & & conglomerates & \\
\hline & \multirow{3}{*}{$\begin{array}{l}\text { Miocene } \\
(1300 \mathrm{~m})\end{array}$} & $\begin{array}{l}\text { Kechabta-Oued } \\
\text { el Khedim }\end{array}$ & $\begin{array}{l}\text { sandstone, clay, } \\
\text { rare conglomerates }\end{array}$ & \\
\hline & & Oued Mellah & marl and gypsum & \\
\hline & & Hakima & $\begin{array}{l}\text { sandstone, breccia, } \\
\text { conglomerates, marls }\end{array}$ & \\
\hline \multirow{5}{*}{ Paleogene } & $\begin{array}{l}\text { Oligocene } \\
(75 \mathrm{~m})\end{array}$ & Fortuna & sandstone & \\
\hline & $\begin{array}{l}\text { Upper Eocene } \\
(35 \mathrm{~m})\end{array}$ & Souar & marls, nummulitic & \multirow{3}{*}{$d>2.4$} \\
\hline & \multirow{2}{*}{$\begin{array}{l}\text { Ypresien- } \\
\text { lower Lut } \\
(150 \mathrm{~m})\end{array}$} & & & \\
\hline & & Metlaoui & $\begin{array}{l}\text { limestones and et } \\
\text { nummulitic limestones }\end{array}$ & \\
\hline & $\begin{array}{l}\text { Paleocene } \\
(300 \mathrm{~m})\end{array}$ & el Haria & marls & $1.7<d<1.95$ \\
\hline \multirow{6}{*}{$\begin{array}{l}\text { Upper } \\
\text { Cretaceous }\end{array}$} & $\begin{array}{l}\text { Campanian- } \\
\text { Maastrichtian } \\
(365 \mathrm{~m})\end{array}$ & Abiod & $\begin{array}{l}\text { limestones, marls } \\
\text { et marly calcareous }\end{array}$ & \multirow{3}{*}{$d \approx 1.9$} \\
\hline & \begin{tabular}{|l|}
$\begin{array}{l}\text { Santonian } \\
(500 \mathrm{~m})\end{array}$ \\
$\begin{array}{l}\text { Coniacian } \\
(50 \mathrm{~m})\end{array}$ \\
\end{tabular} & \multirow[t]{2}{*}{ el Kef } & \multirow[t]{2}{*}{$\begin{array}{l}\text { marl and clay } \\
\text { with rare intercalations } \\
\text { of limestone } \\
\text { and marly limestone }\end{array}$} & \\
\hline & \multirow{2}{*}{\begin{tabular}{|l|} 
Turonian \\
$(130 \mathrm{~m})$ \\
\end{tabular}} & & & \\
\hline & & \multirow{2}{*}{ Bahloul } & \multirow{2}{*}{$\begin{array}{l}\text { black limestones } \\
\text { finely bedded }\end{array}$} & \multirow{3}{*}{$d \approx 2.4$} \\
\hline & \multirow{2}{*}{$\begin{array}{l}\text { Cenomanian } \\
(>250 \mathrm{~m})\end{array}$} & & & \\
\hline & & \multirow[b]{2}{*}{ Fahdene } & \multirow[b]{2}{*}{$\begin{array}{l}\text { marl and } \\
\text { platy limestone }\end{array}$} & \\
\hline \multirow{3}{*}{$\begin{array}{l}\text { Lower } \\
\text { Cretaceous }\end{array}$} & \begin{tabular}{|l|} 
Albian \\
$(500 \mathrm{~m})$
\end{tabular} & & & \multirow{3}{*}{$2.38<d<2.41$} \\
\hline & $\begin{array}{l}\text { Aptian } \\
(500 \mathrm{~m})\end{array}$ & & $\begin{array}{l}\text { marl, marly calcareous } \\
\text { limestone, sandstone }\end{array}$ & \\
\hline & $\begin{array}{l}\text { Barremian } \\
(\approx 200 \mathrm{~m})\end{array}$ & IM Cnerga & marl, marly calcareous & \\
\hline \multicolumn{3}{|l|}{ Trias } & gypsum, carbonates & $1.75<d<2.6$ \\
\hline
\end{tabular}


In relation to Africa-Europe collision, northern Tunisia underwent several compressional tectonic events. A first episode, recently attributed to the Middle Eocene (Perthuisot 1974, Adil 1993), is still a matter of discussion; however, a consensus is reached on the occurrence of three major phases dated as Middle Miocene, Late Miocene, and earliest Pliocene. The most important one, referred to as the "Atlasic phase", was responsible for important folding and reactivated diapiric movement of Triassic deposits also interpreted as salt glaciers by some authors (Vila 1995). These NE-SW trending Triassic chaotic material as well as a set of curved axis folds mainly characterize the present "Diapirs zone" of northern Tunisia. In this area, anticlines are narrow and asymmetrical with faulted south-eastern flanks; synclines are wide and infilled by Neogene deposits. Four major fault types can be identified considering their general trends: N-S, NE-SW, SE-NW, and E-W (Perthuisot and Jauzein 1972, Perthuisot 1978, 1979; Hammami 1999, Kadri and Ben Haj Ali 1999, El Ouardi 2002, Chikhaoui 2002, Balti et al. 2014). The stratigraphic data (Table 1) includes various successions of Triassic-to-Quaternary ages with the lack of Jurassic series.

\section{GRAVITY DATA}

Gravity data were gathered by the Val d'Or Sagax company for the Tunisian geological survey (ONM 2000). They concern 648 regularly distributed stations covering the map section of the Teboursouk area. The approximately mean density is one observation per square kilometer. A Lambert North projection using the Clark ellipsoid 1880 and Carthage datum was adopted. Free-air and Bouguer gravity corrections were performed using sea level datum and a reduction density of $2.4 \mathrm{~g} / \mathrm{cm}^{3}$. This value results from the comparison of several methods: direct measurement of densities over several samples, and using the indirect Nettleton's method.

\subsection{Bouguer anomaly map}

The Bouguer gravity anomaly map $\left(d=2.4 \mathrm{~g} / \mathrm{cm}^{3}\right)$ of the study area shows a variation of $34 \mathrm{mGals}$. Three anomaly groups bounded by strong gravity gradients can be identified (Fig. 2) considering their trends.

口 NW-SE: these anomalies consist of $\mathbf{B}_{1}^{+}$(Tabet Ech Cherif syncline), $\mathbf{B}_{1}$ (along Khalled-Ain el Hamra-Dougga), $\mathbf{B}_{3}{ }^{-}$(Teboursouk), and $\mathbf{B}_{7}{ }^{-}$(El Aroussa plain);

- NE-SW: following this direction, the anomalies $\mathbf{B}_{2}{ }^{+}, \mathbf{B}_{3}{ }^{+}, \mathbf{B}_{4}{ }^{-}$, and $\mathbf{B}_{5}{ }^{+}$are of weak gradients and coincide with the Triassic outcrops of Ain Jamela, Jebel Ech Cheid, Ain Tounga-Khalled, and Thibar, respectively. $\mathbf{B}_{\mathbf{8}}{ }^{-}$ characterizes the Ain el Hamra-Dougga syncline, $\mathbf{B}_{5}{ }^{-}$and $\mathbf{B}_{6}{ }^{-}$correspond to the plains of Khalled and El Aroussa; 


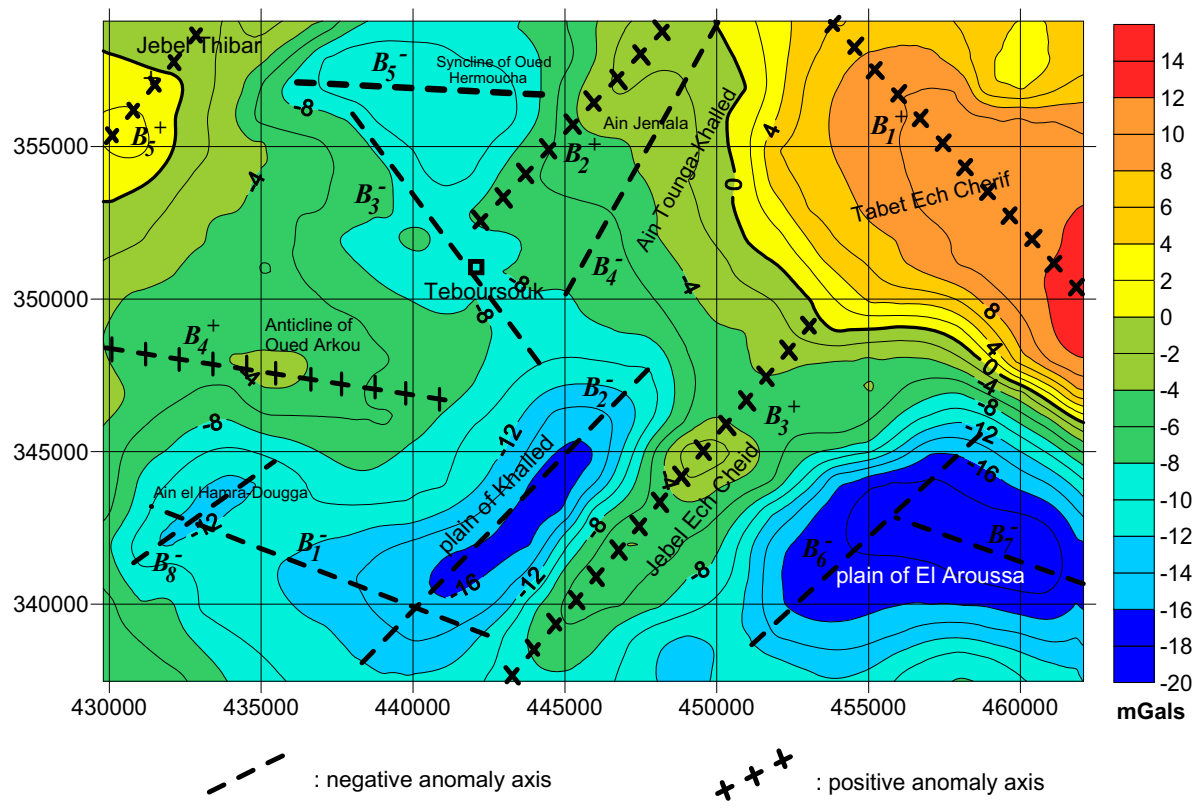

Fig. 2. Bouguer anomaly map of Teboursouk $(d=2.4)$.

a E-W: $\mathbf{B}_{4}{ }^{+}$and $\mathbf{B}_{5}{ }^{-}$overprint the Oued Arkou anticline and the Oued Hermoucha syncline, respectively.

\subsection{Methods and results of interpretation of gravity anomalies}

Various techniques, such as vertical and horizontal derivatives, Euler deconvolution, and upward continuation, were used to interpret the gravity map. The programs used for the gravity data interpretation in this study are the Geosoft and keating programs (Keating 1998).

\section{Vertical derivative $\left(\frac{\delta g}{\delta z}\right)$}

Vertical derivatives of anomalies provide a powerful technique for enhancing anomalies of smaller and near surface geological features (Evjen 1936, Baranov 1953, Marson and Klingele 1993). This derivative allows to identify the structures in the subsurface from the Bouguer anomaly. Indeed, the transformation reduces the regional element (low-frequency anomalies) which may distort or even hide the relationships near surface geological features (high-frequency anomalies) and the shape of the anomalies. Positive zones indicate rock densities exceeding the average and vice versa. Consequently a vision on sub-outcropping lithologies is possible and distinguished raised zones are characterized by positive anomalies where heavier platform 


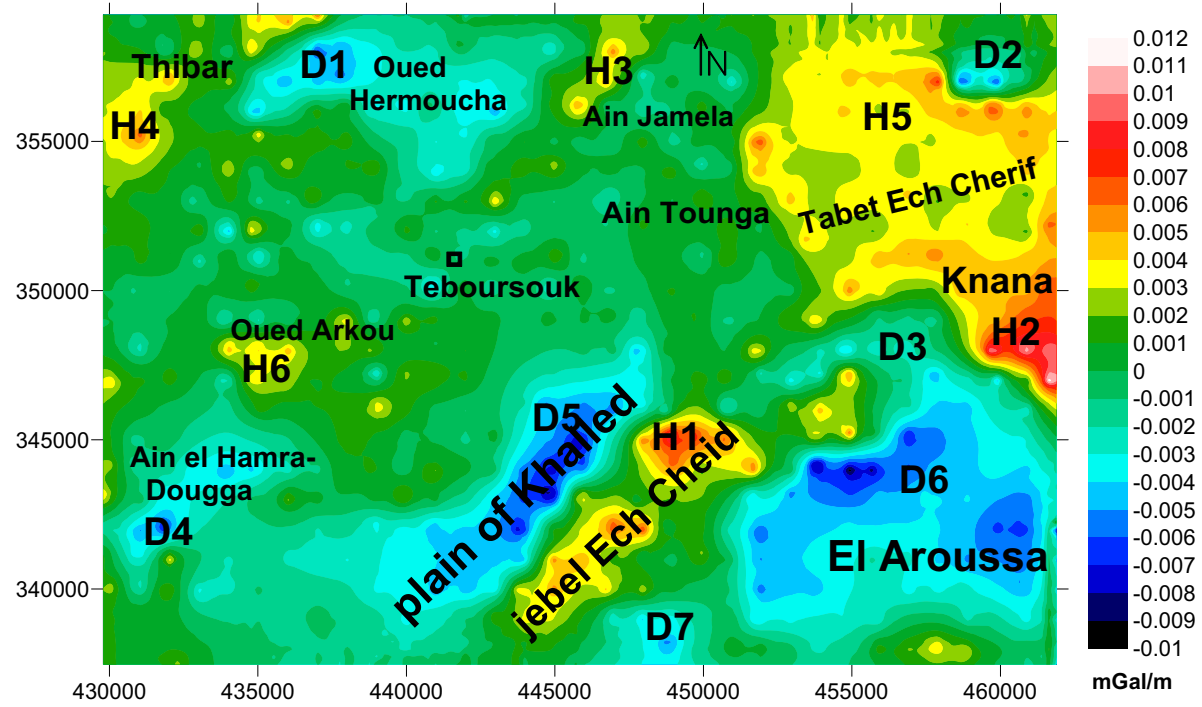

Fig. 3. First vertical derivative of the Bouguer anomaly.

is either closer to the surface or showing a light and thin cover. On the other hand, depression zones are characterized by negative anomalies indicating a light and thick cover.

Figure 3 shows that, in our case study, the raised zones are related to the Triassic outcrops $\left(\mathbf{H}_{\mathbf{1}}-\mathrm{J}\right.$. Ech Cheid; $\mathbf{H}_{\mathbf{2}}-$ Knana; $\mathbf{H}_{\mathbf{3}}-$ Ain Jamela; $\mathbf{H}_{\mathbf{4}}-$ Thibar), to the Cretaceous series of Tabet Ech Cherif $\left(\mathbf{H}_{5}\right)$ and to the Neogene outcrops of the Oued Arkou anticline $\left(\mathbf{H}_{\mathbf{6}}\right)$.

These raised zones strongly contrast with depressive ones filled in by light and thick series which are, from north to south: $\mathbf{D}_{\mathbf{1}}$ (Pliocene deposits of Oued Hermoucha), $\mathbf{D}_{2}$ (NE the study area), $\mathbf{D}_{\mathbf{3}}$ (between Jebel Ech Cheid and Knana), $\mathbf{D}_{4}$ (Ain el Hamra-Dougga), $\mathbf{D}_{5}$ (the plain of Khalled), $\mathbf{D}_{6}$ (two distincts subdepressions in El Aroussa), and $\mathbf{D}_{7}$ (southern J. Ech Cheid).

The association of horizontal gradient $\left(\frac{\delta g}{\delta(x, y)}\right)$ and the upward continuation

The association of horizontal gradient and the upward continuation is used for the identification of the deep faults' limits and their dips (Cordell and Grauch 1985, Blakely and Simpson 1986, Blakely 1996, Phillips 1998, Archibald et al. 1999, Everaerts and Mansy 2001, Khattach et al. 2004, Najine et al. 2006, Chennouf et al. 2007, Abderbi and Khattach 2010). The Bouguer anomalies were prolonged to heights up to $4000 \mathrm{~m}$ with a step of $250 \mathrm{~m}$. For each level, the maxima of the horizontal gradient were localized. 


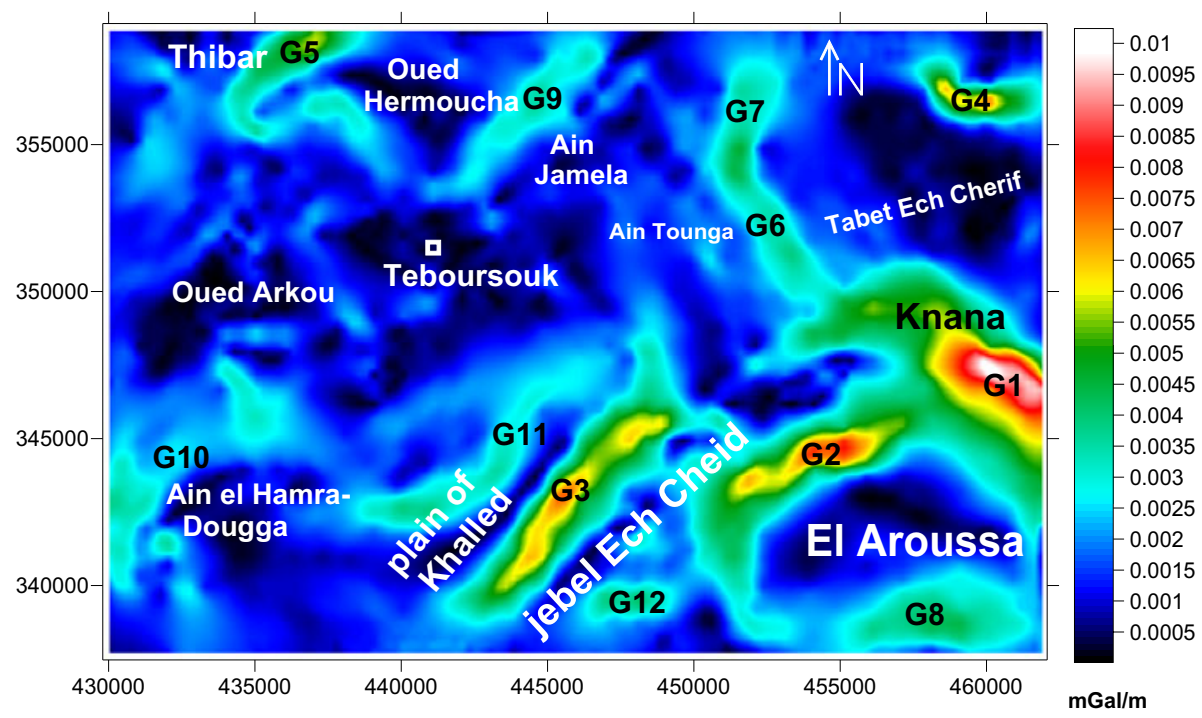

Fig. 4. Horizontal gradient map.

If the structures are vertical, all maxima are overprinting. On the other hand, the shifting of maxima for the upward extension indicates the direction of the dip.

Zones with strong gradients as shown by Fig. 4 are:

口 G1 $(0.01 \mathrm{mGal} / \mathrm{m})$ : trending NW-SE, this zone marks a rooted and suboutcropping fault (loose iso-anomalous contours) between Cretaceous series (north to the rift: high zone) and those of El Aroussa basin: low zones. This limit would correspond to the NE edge of El Aroussa;

口 $\mathbf{G 2}(0.008 \mathrm{mGal} / \mathrm{m})$ and $\mathbf{G 3}(0.007 \mathrm{mGal} / \mathrm{m})$ on both sides of Jebel Ech Cheid are of a ENE-WSW and NE-SW trend;

a G4 $(0.007 \mathrm{mGal} / \mathrm{m})$ trending E-W, overprints Oued Siliana and indicates a vertical deep fault separating Tabet Ech Cherif from a basin located to the NE of the study area. This fault underlines the contact between Triassic outcrops and Cretaceous series of Tabet Ech Cherif.

Other zones with weaker horizontal gradients $(<0.006 \mathrm{mGal} / \mathrm{m})$ are also shown in Fig. 4. These consist of: G5 (south-eastern Thibar, trending NESW); G6 and G7 (Tabet Ech Cherif; NW-SE and NNE-WSW, respectively); G8 (south to El Aroussa, NNE-SSW); G12 (Ech Cheid, E-W); G11 (plain of Khalled, flexure), G9 (North Ain Jamela, NE-SW), and G10 (NW flank and the periclinal termination of Ain el Hamra-Dougga syncline).

The superposition of the maxima of horizontal gradients (Fig. 5) shows that some faults are sub-vertical: F1, F2, F3, and F4 delimiting the Jebel 


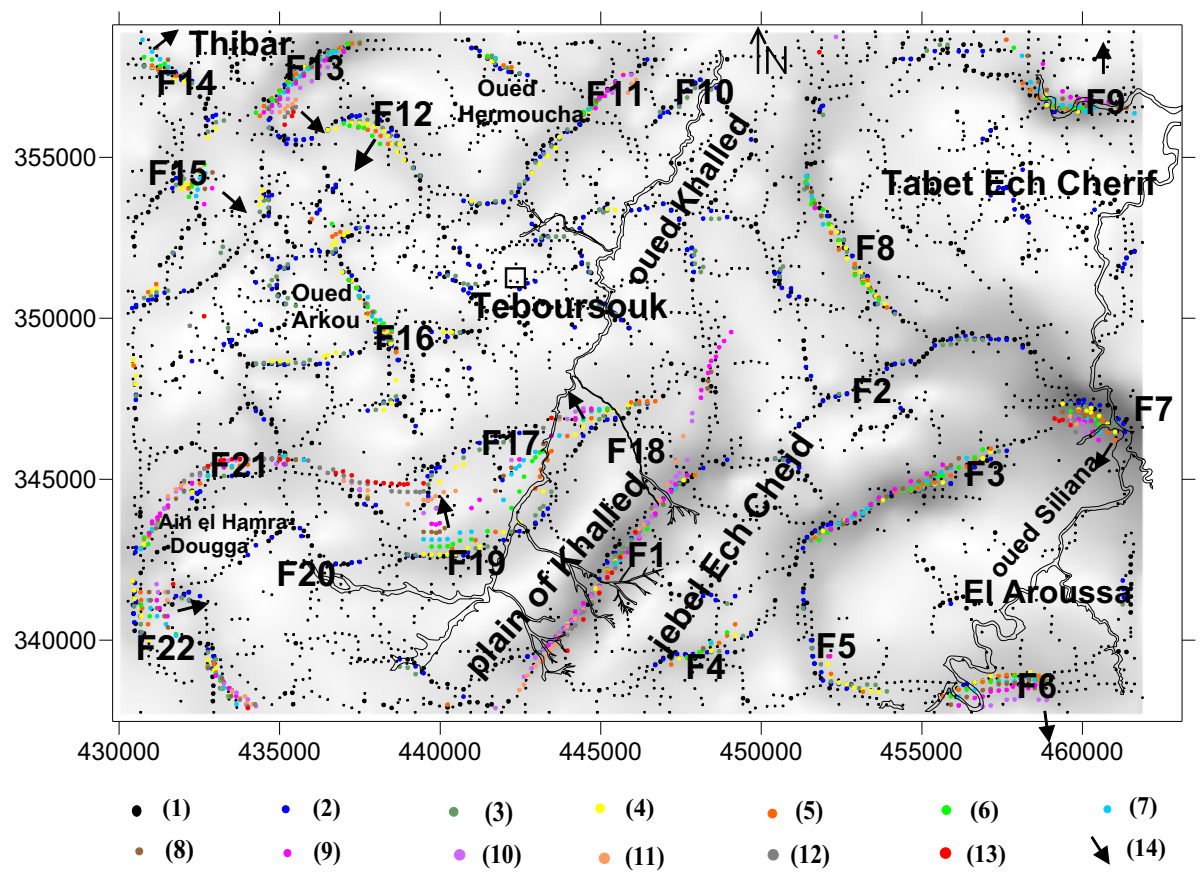

Fig. 5. Superposition of horizontal gradient maxima obtained from the Bouguer anomaly and from upward continuation map at different altitudes: (2) $250 \mathrm{~m}$, (3) $500 \mathrm{~m}$, (4) $750 \mathrm{~m}$, (5) $1000 \mathrm{~m}$, (6) $1250 \mathrm{~m}$, (7) $1500 \mathrm{~m}$, (8) $1750 \mathrm{~m}$, (9) $2000 \mathrm{~m}$, (10) $2500 \mathrm{~m}$, (11) $3000 \mathrm{~m}$, (12) $3500 \mathrm{~m}$, (13) $4000 \mathrm{~m}$, and (14) dip direction.

Ech Cheid; F5 and F17 affecting the plains of El Aroussa and Khalled, respectively; F16 close to the Oued Arkou anticline; F8 crossing the Tabet Ech Cherif syncline, and F11 in Oued Hermoucha. The other faults show various dipping trends; from east to west they are: F9 (N-dipping, located to the north-eastern extremity of the sector); F7 (SW-dipping, NE J. Ech Cheid nearby Ragoubet el Mahjbia); F6 (S-dipping, north to J. Strassif); F18 and F19 (NW-dipping, plain of Khalled), F12 (SW-dipping, Oued Hermoucha); F13 (SE-dipping, SW J. Thibar); F14 (NE-dipping, Jebel Thibar), F15 (SEdipping, NW J. Goraa), and F22 (east-dipping, Ain el Hamra-Dougga syncline).

The digitization and statistic processing of the gravimetric contacts (Fig. 6: Map 1 and panel A) reveal four fault trending groups: N-S, E-W, N30 to N70, and N120 to N150. This is in line with the geological map structures where the N40, E-W, N140, and N-S trends predominate (Fig. 6: Map 2 and panel B). The outline length of structures is nevertheless different. 


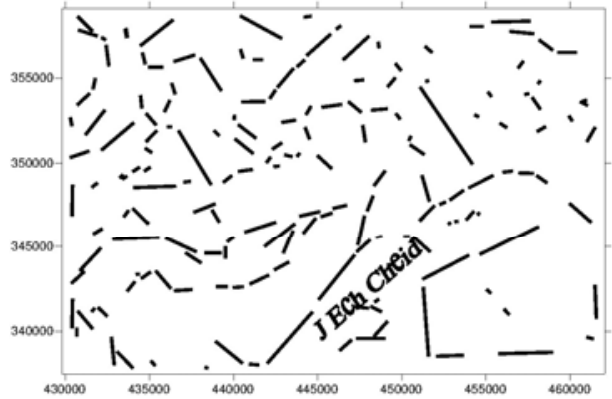

Map1 : Gravimetric lineaments map and (A) its statistical analysis.

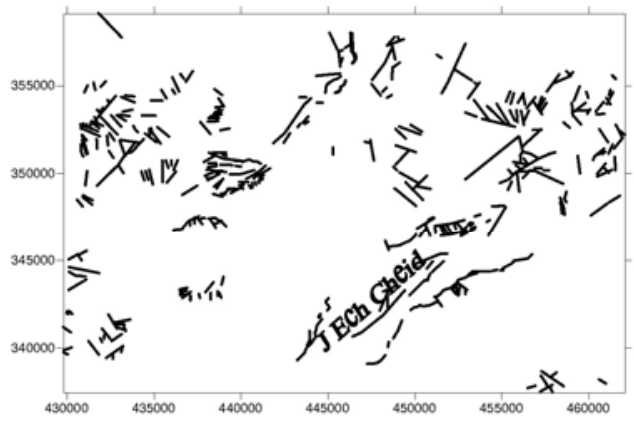

Map2 : Observed lineament map in geology and (B) its statistical analysis.

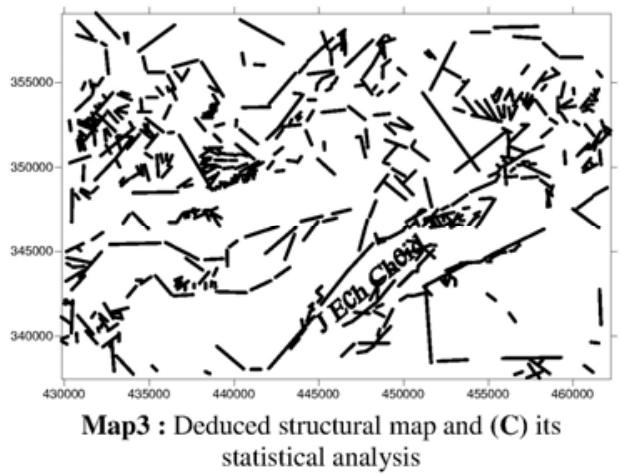

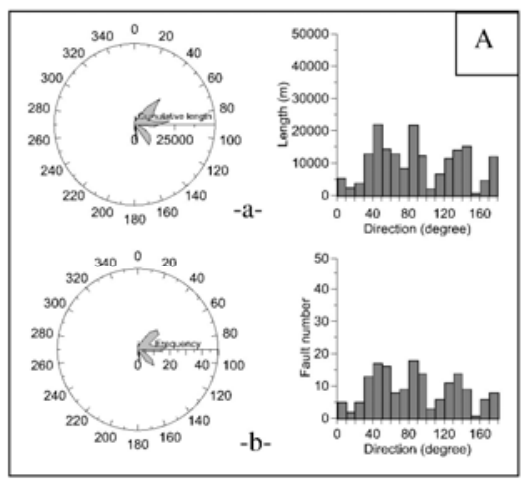
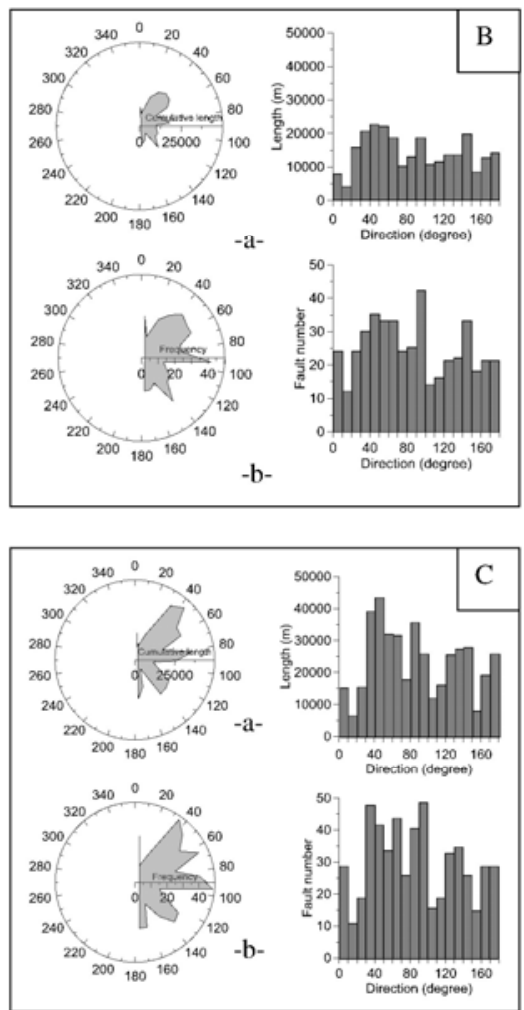

Fig. 6. Statistical analysis of accident directions obtained on the various maps: (a) rose and histogram of cumulated lengths in meter, (b) rose and histogram of frequencies. 
As far as frequencies are concerned (Fig. 6: panels A and B), the identified trends are ordered from high to low as follows: E-W, N40, N135, and $\mathrm{N}-\mathrm{S}$. The final structural map obtained shows a predominance of the trends E-W, N30 to N60, N130 and N-S (in number) and of the N40, E-W, N140, and N-S trends (for the length outlines) (Fig. 6: Map 3 and panel C).

Among the identified structures, some fault outlines obtained from the processed gravimetric data and those plotted on the geological map of Teboursouk (Fig. 6: Map 1) are identical (e.g., NE-SW-trending ones of southern J. Chehid Triassic outcrops) or complementary (Fig. 6: Maps 2 and 3).

\section{The Euler deconvolution}

The Euler deconvolution allows the horizontal location and the depth estimation of contacts (Thompson 1982, Reid et al. 1990, Keating 1998, AsfiraneHaddadj and Galdeano 2000, Mushayandebvu et al. 2004, Khattach et al. 2004, Chennouf et al. 2007, Saibi et al. 2012). It depends essentially on grid spacing, size of the deconvolution windows, and structural index (Barbosa et al. 2002, Stavrev and Reid 2007, Melo et al. 2013). Based on the calculation of horizontal gradient $\left(\frac{\delta g}{\delta(x, y)}\right)$, and the vertical gradient $\left(\frac{\delta g}{\delta z}\right)$, the Euler equation is written as follows:

$$
\left(x-x_{0}\right) \frac{\delta g}{\delta x}+\left(y-y_{0}\right) \frac{\delta g}{\delta y}+\left(z-z_{0}\right) \frac{\delta g}{\delta z}=-N T(x, y),
$$

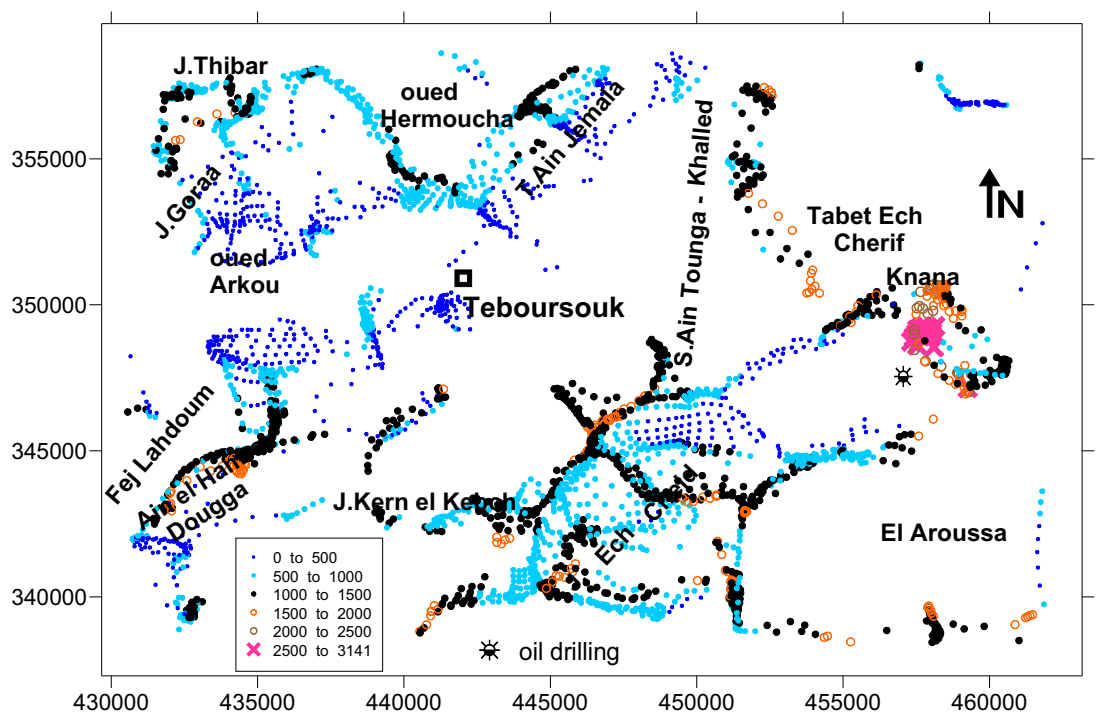

Fig. 7. Euler solution map (structural index of $0.25,10 \times 10$ windows, maximum relative error of $15 \%)$. 
where $\left(x_{0}, y_{0}, z_{0}\right)$ are the coordinates of a gravimetric source, $g$ is the intensity of the measured field to $(x, y, z), N$ is the structural index and refers to the source geometry.

For good horizontal localization and source alignment we chose a structural index (SI) of 0.25 .

In our case study (Fig. 7), the Euler deconvolution highlights the presence of some faults reaching $3141 \mathrm{~m}$ depth. The dominating faults in this area are ranging between 500 and $1500 \mathrm{~m}$. The Euler solution highlights also that the Khalled basin is limited by a deep faults raging from 1500 to $2000 \mathrm{~m}$.

However, several faults previously identified are absent in the Euler solution.

This is may be due to the fact that densities do not contrast enough with depths; the interference of close source responses is also a potential cause.

\section{DISCUSSION}

As a synthesis, the results obtained from the Euler solution, correlated to the geological data, allow to propose a new structural map for the Teboursouk area (Fig. 8a) which shows:

口 NE-SW trending faults of important depths around J. Ech Cheid (F1, F2, and F3), Fej Lahdoum (F21), and Thibar (F13). Their depth varies from 500 to $1500 \mathrm{~m}$, sometimes reaching $2000 \mathrm{~m}$. These faults are controlling the upward movement of Triassic material. Elsewhere, the NE-SW trending faults are less deep. For the Teboursouk major fault (F10), the gravity data show an insignificant depth in the study area; however, the seismic reflection data have shown an important depth exceeding $1500 \mathrm{~m}$ (TOTAL 1978, Gasmi 2002).

- E-W trending major faults are less numerous; however, they have an important role in the structure of the area, such as from north to south: (i) in the north-eastern the study area, the fault $\mathbf{F 9}$ is north-dipping with a depth exceeding $1000 \mathrm{~m}$. It coincides with Oued Siliana and may explain its sudden change in flow direction. The relationship of the fault $\mathbf{F 9}$ with the Triassic outcrop on this site is more than probable; (ii) on the eastern edge of J. Ech Cheid, along the Koudiat Tellilet-Koudiat Guella alignment, the $1500 \mathrm{~m}$ deep fault $\mathbf{F 2 3}$ could be responsible for the arched aspect of Jebel Ech Cheid. The Lakhouat NS-trending fault, well individualized to the south of the study area, may have also played the common role. To the south, from Koudiat Mejemba to Koudiat Bazina Serira, the 500 to $2000 \mathrm{~m}$ deep fault $\mathbf{F} 4$, would be the extension of the fault F5 of northern J. Strassif; (iii) both F19 and F17 faults, with depths up to $1500 \mathrm{~m}$, affect the plain of Khalled and the syncline of Ain el 
Hamra-Dougga, respectively, and are interpreted as responsible for the torsion of this structure.

- N-S-trending faults are either hidden by Quaternary deposits of El Aroussa (depth $=500$ to $2000 \mathrm{~m}(\mathbf{F 5})$ ); or delimited to the east and to the west, the Eocene series of Ain Tounga $(\mathbf{F} 7$ and $\mathbf{F 8}$, depth $=1500 \mathrm{~m})$.

a NW-SE-trending faults are the deepest and show high dipping angles. The vertical F9 affects Tabet Ech Cherif and is considered to be at the origin of the important gradient (Fig. 3). The SW-dipping fault F7 corresponds to the north-eastern limit of El Aroussa graben. F24 constitutes the northern extension of this graben, bordering to the south of the Triassic outcrop of Knana. In this latter locality, major measured depths are from 2000 to $3141 \mathrm{~m}$. Indeed, oil exploration works revealed important Tertiary series $(1800 \mathrm{~m})$ overlying the $1200 \mathrm{~m}$ thick Aptian-Maastrichtian successions. Eventually, in the Oued Hermoucha syncline, the faults F12 and $\mathbf{F} 25$ have depths of about $1500 \mathrm{~m}$.

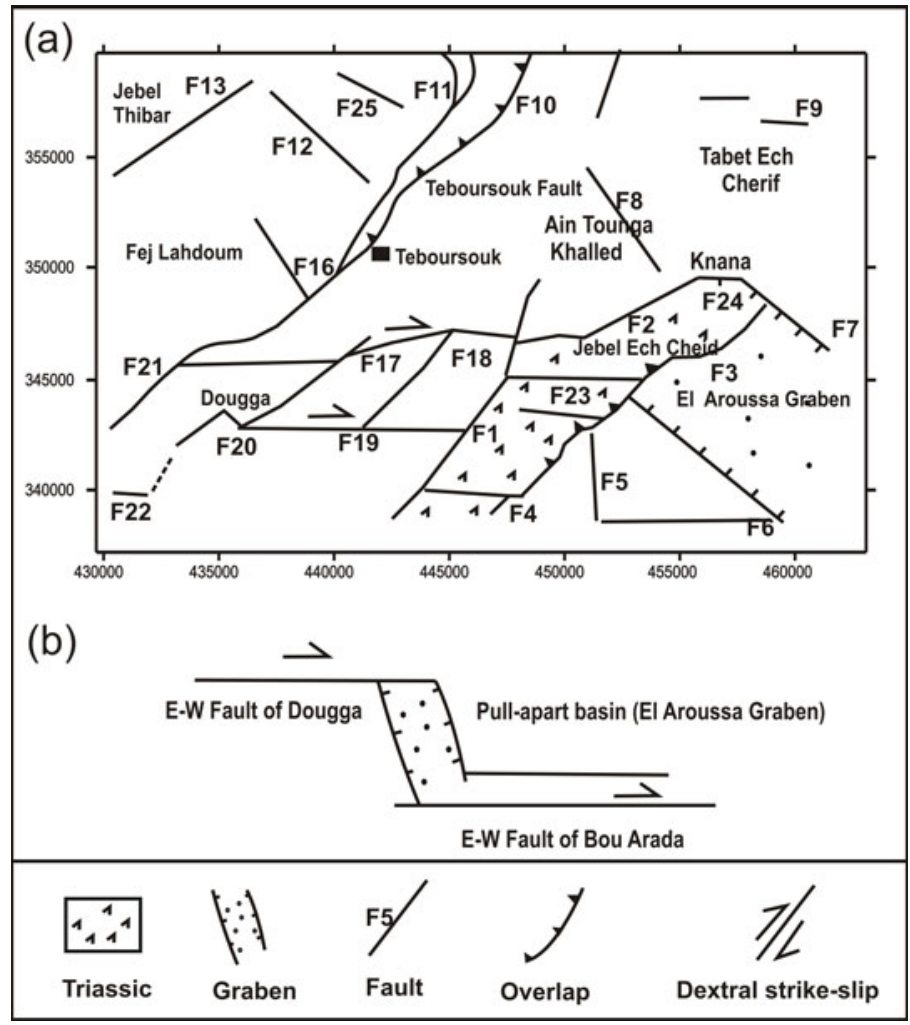

Fig. 8: (a) Synthetic structural map of Teboursouk area, (b) synthetic structure of el Aroussa graben. 
The principal directions described above can be integrated into the local geodynamic context controlled mainly by the NW-SE Atlasic phase of upper Miocene (Tortonian). This compression leads to the individualization of NESW reverse faults and to the reactivation of old normal faults during the Tertiary. During the Aptian, the upward movement of the diapiric structures was activated. As shown in the gravity data, faults bordering the Triassic outcrops can reach $2000 \mathrm{~m}$. This pleads in favor of a deep origin of the Triassic outcrop and defends its diapiric character.

In the south-eastern region, two subparallel normal faults NW-SE limit the graben of El Aroussa. The opening of this graben as a pull apart structure is guided by the E-W dextral strike-slip fault of Dougga and Bou Arada (Fig. 8b). The strike-slip fault of Dougga is linked to Fej Lahdoum one in the east. The N-S sinister strike-slip fault of Fej Lahdoum is the cause of the local derivation of the diapiric structure of Ech Cheid. This tectonics style is typical in the Tunisian Atlas (Jauzein 1967, Ben Ayed 1975, Chihi 1995).

In the western Mediterranean context, the occurrence of graben in northern and central Tunisia is related to the geodynamic evolution of the Maghreb eastern part (Algeria and Tunisia) and the Pelagian Block expansion, from Miocene to actuel. This expansion integrates as part of the general geodynamic evolution of the central and western Mediterranean by the subduction-collision systems of African and Eurasian plates (Chihi 1995).

\section{CONCLUSION}

The qualitative and quantitative analyses of the gravity data have a great interest in the structural studies. Thus, these techniques allowed specifying the structure and highlighting the fault system affecting the Teboursouk area. First of all we deduct the diapiric character of the J. Ech Cheid Triassic and probably the Thibar one, mainly explained by the major deep faults delimiting it $(2000 \mathrm{~m})$. In this study, a deep E-W fault network $(1500 \mathrm{~m})$, going from Fej Lahdoum (no. 18, 19) to J. Ech Cheid (no. 2, 23, 4, and 5) was also highlighted. During the upper Miocene, where the Atlas compressive phase is oriented NW-SE, and the old Quaternary (post villafranchienne), the Dougga E-W faults are dextral strike-slip and affected the architecture of Teboursouk area. Thereby, the megafold axes in Ain Hamra-Dougga, Kern el Kebch, and the J. Ech Cheid anticline are curved and vary from NE-SW to $\mathrm{E}-\mathrm{W}$ direction in the neighbourhood of the E-W faults.

In Teboursouk area, the NW-SE faults are usually buried. This fault network highlighted in this study by the gravity data, affects the substratum and locally appear at the surface when it is reactivated. The fault F10 (Fig. 8a) representing the NE edge of El Aroussa graben seems to be active in the Miocene and delimits a subsiding zone where the Tertiary series reaches 
$1800 \mathrm{~m}$ (TOTAL 1978). The El Aroussa graben is an extensional relay between the E-W Dougga fault and the E-W Bou Arada fault located in the SE of the study area.

Finally, the architecture of this study area has been controlled by the reactivation of the pre-existing deep faults. Thereby, several tectonic structures have been implemented. Gravity data processing is useful in delineating these structures (rootedness and amplitudes) and in mapping, with greater precision (depth and dip), lineations, intrusive and faults within basement rocks that are covered by sedimentary strata. These basement features tend to localize zones of weakness and, therefore, are important to the siting of manmade structure (i.e., dams, water drilling, boreholes).

\section{References}

Abderbi, J., and D. Khattach (2010), Structural setting of the High Plateaus; insights from gravity data analysis (Eastern Morocco), Bull. Inst. Sci., Rabat, Sci. Terre 32, 19-30 (in French).

Adil, S. (1993), Salt Triassic dynamics in northern Tunisia: Pull-apart basins form at stepover, magmatism and mining implication, Ph.D. Thesis, University of Tunis el Manar, Tunisia, 249 pp.

Archibald, N., P. Gow, and F. Boschetti (1999), Multiscale edge analysis of potential field data, Explor. Geophys. 30, 1/2, 38-44, DOI: 10.1071/EG999038.

Asfirane-Haddadj, F., and A. Galdeano (2000), The use of Euler deconvolution and analytic signal for location of magnetic sources, Bull. Soc. Géol. France 171, 1, 71-81 (in French).

Balti, H., F. Hachani, and M. Gasmi (2014), Hydrogeological potentiality assessment of Teboursouk Basin, Northwest Tunisia using electrical resistivity sounding and well logging data, Arab J. Geosci. 7, 7, 2095-2914, DOI: 10.1007/s12517-013-1001-7.

Baranov, V. (1953), Vertical gradient calculation of the gravity field or magnetic field measured at the surface, Geophys. Prospect. 1, 3, 171-191, DOI: 10.1111/j.1365-2478.1953.tb01139.x (in French).

Barbosa, V.C.F., J.B.C. Silva, and W.E. Medeiros (2002), Practical applications of uniqueness theorems in gravimetry: Part II - Pragmatic incorporation of concrete geologic information, Geophysics 67, 3, 795-800, DOI: 10.1190/ 1.1484523 .

Ben Ayed, N. (1975), Geological study of Siliana and Sers synclines (central Tunisian Atlas), Ph.D. Thesis, Pierre and Marie Curie University, Paris VI, France, 82 pp.(in French). 
Ben Ayed, N. (1986), Tectonic Evolution of the Front Alpine Chain from the Mesozoic to Current, Annales des Mines et de la Géologie de Tunisie, Vol. 32, 286 pp. (in French).

Ben Ayed, N. (1994), The convergence of E-W and N-S convergents overthrusting strike slip fault of northern Tunisia: geometry and attempt to reconstruction of deformation conditions. In: Proc. 4th Tunisian Petroleum Exploration Conference, May 1994, Tunis, Tunisia, 25-37 (in French).

Biely, A., P.F. Burollet, and T. Lajmi (1974), Geodynamic studies of Tunisia and neighboring areas of the Mediterranean, Notes Serv. Géol. Tunisie 41, 2338 (in French).

Blakely, R.J. (1996), Potential Theory in Gravity and Magnetic Applications, Cambridge University Press, Cambridge, 464 pp.

Blakely, R.J., and R.W. Simpson (1986), Approximating edges of source bodies from magnetic or gravity anomalies, Geophysics 51, 7, 1494-1498, DOI: 10.1190/1.1442197.

Bolze, J. (1950), Triasic diapirs and orogenic phases in the Teboursouk mountains (Northern Tunisia), C. R. Acad. Sci. Paris 231, 8, 480-482 (in French).

Chennouf, T., D. Khattach, A. Milhi, P. Andrieux, and P. Keating (2007), Main structural trends in northeastern Morocco: The contribution of gravimetry, C. R. Geoscience 339, 6, 383-395, DOI: 10.1016/j.crte.2007.03.006 (in French and abridged English version).

Chihi, L. (1995), Neogene-Quaternary grabens of Tunisia in the Pelagian Sea: their signification in the central mediterranean geodynamic setting, Ph.D. Thesis, University of Tunis II, Tunisia, $324 \mathrm{pp}$. (in French).

Chikhaoui, M. (2002), "Diapir zone" in Tunisia: structure and geodynamic evolution of the Meso-Cenozoic series and the Triassic salt body geometry, Ph.D. Thesis, University of Tunis, Tunisia, 318 pp. (in French).

Chitta, N. (1979), Micropaleontological study of the cretaceous (Aptian to Cenomanian) in Teboursouk region (Northern Tunisia), Ph.D. Thesis, Pierre and Marie Curie University, Paris VI, France, 192 pp. (in French).

Cordell, L., and V.J.S. Grauch (1985), Mapping basement magnetization zones from aeromagnetic data in the San Juan Basin, New Mexico. In: W.J. Hinze (ed.), The Utility of Regional Gravity and Magnetic Anomaly Maps, Society of Exploration Geophysicists, 181-197.

Dali, T. (1997), Geological study of Gafour region, Ph.D. Thesis, Pierre and Marie Curie University, Paris VI, France (in French).

Doglioni, C., M. Fernandez, E. Gueguen, and F. Sabat (1999), On the interference between the early Apennines-Maghrebides backarc extension and the Alps-Betics orogen in the Neogene geodynamics of the Western Mediterranean, Bol. Soc. Geol. Ital. 118, 75-89. 
El Ouardi, H. (2002), Origin of lateral variations of the Ypresian deposits in the dome zone in northern Tunisia, $C$. R. Geoscience 334, 2, 141-146, DOI: 10.1016/S1631-0713(02)01704-2.

Everaerts, M., and J.L. Mansy (2001), Gravimetry contribution in the Boulonnais and Artois areas (France), Bull. Soc. Géol. France 172, 3, 267-274 (in French).

Evjen, H.M. (1936), The place of the vertical gradient in gravitational interpretations, Geophysics 1, 1, 127-136, DOI: 10.1190/1.1437067.

Gasmi, M. (2002), Geophysical contributions in recognition and managment of natural resources in Tunisia, Ph.D. Thesis, National School of Engineers of Sfax, Tunisia, 478 pp. (in French).

Gueguen, E., C. Doglioni, and M. Fernandez (1998), On the post-25 Ma geodynamic evolution of the western Mediterranean, Tectonophysics 298, 1-3, 259-269, DOI: $10.1016 / \mathrm{S} 0040-1951(98) 00189-9$.

Guiraud, R., W. Bosworth, J. Thierry, and A. Delplanque (2005), Phanerozoic geological evolution of Northern and Central Africa: An overview, J. African Earth Sci. 43, 1-3, 83-143, DOI: 10.1016/j.jafrearsci.2005.07.017.

Hachani, F. (2006), Geophysical study by gravimetry of Jebel Ech Cheid and its surroundings (Northern Tunisia): structural implications, M.Sc. Thesis, Faculty of Sciences of Bizerte, Tunisia, 119 pp. (in French).

Hammami, M. (1999), Tectonic, halokinesis and mineralizations in the diapir zone (Northern Tunisia), Ph.D. Thesis, University of Tunis El Manar, Tunisia, 197 pp. (in French).

Jauzein, A. (1967), Contribution to the geological study of the confines of Tunisian dorsal (Northern Tunisia), Ann. Mines Géol. 22, 475 (in French).

Kadri, A., and M. Ben Haj Ali (1999), Elements of thought on est-west and nord-sud tectonic lineaments and associated grabens in northern Tunisia, Note Service Géol. Tunisie 65, 131-140 (in French).

Keating, P.B. (1998), Weighted Euler deconvolution of gravity data, Geophysics 63, 5, 1595-1603, DOI: 10.1190/1.1444456.

Khattach, D., P. Keating, M. Mili, T. Chennouf, P. Andrieux, and A. Milhi (2004), Contribution of gravimetry to the study of Triffa basin structure (northestern Morocco): hydrogeological implications, C. R. Geoscience 336, 16, 1427-1432, DOI: 10.1016/j.crte.2004.09.012 (in French and abridged English version).

Marson, I., and E.E. Klingele (1993), Advantages of using the vertical gradient of gravity for 3-D interpretation, Geophysics 58, 11, 1588-1595, DOI: 10.1190/1.1443374.

Melo, F.F., V.C.F. Barbosa, L. Uieda, V.C. Oliveira Jr., and J.B.C. Silva (2013), Estimating the nature and the horizontal and vertical positions of 3D magnetic sources using Euler deconvolution, Geophysics 78, 6, J87-J98, DOI: 10.1190/geo2012-0515.1. 
Mushayandebvu, M.F., V. Lesur, A.B. Reid, and J.D. Fairhead (2004), Grid Euler deconvolution with constraints for 2D structures, Geophysics 69, 2, 489496, DOI: 10.1190/1.1707069.

Najine, A., M. Jaffal, K. El Khammari, T. Aifa, D. Khattach, M. Himi, A. Casas, S. Badrane, and H. Aqil (2006), Contribution of gravimetry to the structural study of the Tadla basin: hydrogeological implications, C. R. Geoscience 338, 10, 676-682, DOI: 10.1016/j.crte.2006.04.015 (in French and abridged English version).

ONM (2000), Gravimetric campaign CG3. Teboursouk 1:50 000 map, National Office of Mines, Tunis, Tunisia.

Perthuisot, V. (1974), Middle Eocene in Teboursouk region (diapir zone, northern Tunisia); paleogeographic and structural implications, Bull. Soc. Géol. France S7-16, 3, 319-323, DOI: 10.2113/gssgfbull.S7-XVI.3.319 (in French).

Perthuisot, V. (1978), Dynamic and petrogenesis of Triassic salt extrusions in northern Tunisia, Ph.D. Thesis, Pierre and Marie Curie University, Paris VI, France, 312 pp. (in French).

Perthuisot, V. (1979), Explanatory notes for geological map of Tunisia. Sheet 33, Teboursouk, National Office of Mines, Tunisia, 52 pp. (in French).

Perthuisot, V., and A. Jauzein (1972), El Alia-Tbessa fault in Teboursouk region, Notes Serv. Géol., Trav. Géol. Tunis. 8, 58-63 (in French).

Phillips, J.D. (1998), Processing and interpretation of aeromagnetic data for the Santa Cruz Basin - Patahonia Mountains area, south-central Arizona, Open-File Rep. 2002-98, U.S. Geological Survey, Reston, U.S.A.

Reid, A.B., J.M. Allsop, H. Granser, A.J. Millett, and I.W. Somerton (1990), Magnetic interpretation in three dimensions using Euler deconvolution, Geophysics 55, 1, 80-91, DOI: 10.1190/1.1442774.

Rigane, A., and C. Gourmelen (2011), Tunisian Transtensive Basins in Tethyan Geodynamic Context and Their Post-Tortonian Inversion. In: U. Schattner (ed.), New Frontiers in Tectonic Research - At the Midst of Plate Convergence, InTech, Rijeka, 27-48, DOI: 10.5772/18833.

Rouvier, H. (1985), Geology of Extreme North Tunisia: Tectonics and Paleogeographies Superposed to the Eastern Part of the Northern Maghreb Chain, Annales des Mines et de la Géologie de Tunisie, Vol. 29, 425 pp. (in French).

Saibi, H., E. Aboud, and S. Ehara (2012), Analysis and interpretation of gravity data from the Aluto-Langano geothermal field of Ethiopia, Acta Geophys. 60, 2, 318-336, DOI: 10.2478/s11600-011-0061-x.

Solignac, M. (1927), Geological Study of Northern Tunisia, Université Lyon and Direction Générale Travaux Publics, Tunis, 756 pp. (in French). 
Stavrev, P., and A. Reid (2007), Degrees of homogeneity of potential fields and structural indices of Euler deconvolution, Geophysics 72, 1, L1-L12, DOI: 10.1190/1.2400010.

Thompson, D.T. (1982), EULDPH: A new technique for making computer-assisted depth estimates from magnetic data, Geophysics 47, 1, 31-37, DOI: 10.1190/1.1441278.

TOTAL (1978), Synthetic structural map of Teboursouk permit (P. De Genevraye), Report No. E7759-421, ranking No. 4454, French Oil and Gaz Co. TOTAL, Tunisia.

Vila, J.M. (1995), First terrestrial study of a large submarine salt glacier - The eastern part of the Ouenza-Ladjebel-Meridef structure (Algerian Tunisian Confines) - Proposal for an emplacement scenario and comparisons, Bull. Soc. Géol. France 166, 2, 149-167 (in French). 